\title{
Emission spectroscopy and kinetic fluorometry studies of phototrophic microbial communities along a salinity gradient in solar saltern evaporation ponds of Eilat, Israel
}

\author{
Ondřej Prášil ${ }^{1, *}$, David Bína ${ }^{2}$, Hana Medová1 ${ }^{1}$ Klára Řeháková ${ }^{3,4}$, \\ Eliška Zapomělová ${ }^{4}$, Jana Veselá ${ }^{5}$, Aharon Oren $^{6}$ \\ ${ }^{1}$ Institute of Microbiology, ASCR, Opatovický mlýn, Třeboň 379 81, and Institute of Physical Biology, \\ University of South Bohemia, Nový Zámek 136, Nové Hrady 373 33, Czech Republic \\ ${ }^{2}$ Institute of Plant Molecular Biology, Biology Centre, ASCR, Branišovská 31, České Budějovice 37005 , \\ and Institute of Physiology, ASCR, Vídeňská 1083, Prague 14220, Czech Republic \\ ${ }^{3}$ Institute of Hydrobiology, Biology Centre, ASCR, Na Sádkách 7, České Budějovice 370 05, Czech Republic \\ ${ }^{4}$ Institute of Botany, ASCR, Dukelská 135, Třeboñ 379 82, Czech Republic \\ ${ }^{5}$ Department of Botany, Faculty of Sciences, Charles University, Benátská 2, Prague 2, 128 01, Czech Republic \\ ${ }^{6}$ Department of Plant and Environmental Sciences, The Institute of Life Sciences, and the Moshe Shilo Minerva Center \\ for Marine Biogeochemistry, The Hebrew University of Jerusalem, Jerusalem, Israel
}

\begin{abstract}
The planktonic and benthic microbial communities in 8 hypersaline evaporation ponds of the Israel Salt Company in Eilat, Israel, with salinities ranging from 58 to $329 \mathrm{~g} \mathrm{l}^{-1}$ (total dissolved salt), were studied using fluorescence emission spectroscopy and kinetic fluorometry. With increasing salinity, the anoxygenic phototrophic bacteria (containing bacteriochlorophyll $a$, bchl $a$ ) formed a significant and increasing fraction of the planktonic phototrophic biomass. While the bchl $a / c h l a$ molar ratio was 0.01 at the lowest salinity, it reached almost 1 at the higher salinities. In the benthic communities, emission spectroscopy revealed depth-dependent changes in the photophysiology of benthic oxygenic phototrophs, and spatial variability in the abundance of several groups of anoxygenic photosynthetic bacteria (green bacteria containing chlorosomes and purple bacteria containing LH1). In general, the emission signal of the benthic oxygenic phototrophs (diatoms and Cyanobacteria) was dominated by photosystem I (detected in some cases down to $5 \mathrm{~cm}$ of sediment depth). The signal of photosystem II and phycobilisomes was several times weaker and was observed mostly in the surface layers. The spectroscopic data of microbial communities were complemented by microscopic characterization.
\end{abstract}

KEY WORDS: Phototrophic microbial communities · Hypersaline - Cyanobacteria • Plankton • Emission spectroscopy $\cdot$ Kinetic fluorometry

\section{INTRODUCTION}

Multi-pond solar salterns, used worldwide for salt production along the coasts in tropical and subtropical areas, present us with an environment with increasing salt concentrations, from seawater to $\mathrm{NaCl}$ saturation. Rich and varied communities of photosynthetic microorganisms develop along the salt gradient, both in the water of the ponds and in benthic mats. Among the organisms encountered are eukaryotic microalgae such as the green alga Dunaliella, which is typically found in the hypersaline brines of the crystallizer ponds, diatoms that are present in the benthic and planktonic communities at lower salinities, different types of unicellular and filamentous Cyanobacteria that often display colorful layers in the gypsum crusts covering the bottom of ponds with 
salinities of $\sim 150$ to $200 \mathrm{~g} \mathrm{l}^{-1}$, and anoxygenic phototrophs such as purple sulfur bacteria, which are often found below the benthic cyanobacterial communities (Cornée 1982, Caumette et al. 1994, Sørensen et al. 2004, 2005, Ionescu et al. 2007, Oren 2009, this Special Issue).

In view of the presence of dense communities of phototrophs as well as the great diversity of photosynthetic microorganisms found along the salt gradient, salterns are ideal systems for the study of primary production and other photosynthesis-related processes in the natural environment (Oren 2009). A multidisciplinary study was therefore conducted on the microbiology of the solar salterns of Eilat, Israel. Aspects investigated included the characterization of the phototrophic microbial communties in the ponds and measurements of primary production using oxygen microelectrodes (Sørensen et al. \&, this Special Issue; Woelfel et al. 2009, this Special Issue) and planar optodes (Woelfel et al. 2009). To complement the classical taxonomic approach, we applied emission spectroscopy and kinetic fluorometry techniques that allowed us to obtain semi-quantitative and qualitative information on the presence of individual groups of phototrophic microorganisms, based on their specific pigment-protein complexes.

\section{MATERIALS AND METHODS}

Site description and sample collection. The sampling sites are situated in the saltern evaporation ponds of the Israel Salt Company at Eilat near the Red Sea coast of Israel and Ein Evrona, which is $10 \mathrm{~km}$ north of the city of Eilat. The plant is a network of connected ponds and channels with a salinity gradient of 58 to $329 \mathrm{~g} \mathrm{l}^{-1}$ (total dissolved salt). The ponds are labeled with company numerical codes 61, 62, 63, 64, 103, 200, 201 and 304. The corresponding salinities of the ponds were $62,88,58$, $114,157,206,303$ and $329 \mathrm{~g} \mathrm{l}^{-1}$, respectively. Ponds were sampled in March 2008, using a $20 \mu \mathrm{m}$ mesh plankton net for plankton, and sterile spatulas and hammers for benthic mats and crusts. The samples of individual layers were placed in plastic tubes and stored at $4^{\circ} \mathrm{C}$ until spectroscopic analysis or fixed with $4 \%$ formaldehyde for species identification. Table 1 shows the chemical parameters and salinity of individual ponds. All samples were collected around midday to limit possible variability due to migration of benthic organisms between the layers, which can be caused by diel vertical oscillation in oxygen and sulfide gradients. The thickness of the benthic communities in the studied ponds varied from a $0.3 \mathrm{~cm}$ mud layer in Pond 61 to a $10 \mathrm{~cm}$ thick stratified gypsum crust with layers of various colors in Ponds 200 and 201. Where possible, the layers of the community were sampled separately for the identification of species and spectroscopic analysis.
Emission spectroscopy. The method utilizes the fact that many of the characteristic pigment-protein complexes of phototrophic organisms emit fluorescence at different and characteristic wavelengths when cooled to low temperature. For example, phycobilisomes (PBS) typically emit in the range of 600-660 nm, photosystem II (PSII) at 685 and $695 \mathrm{~nm}$, photosystem I (PSI) at 700-730 nm, bacterial LH I complex at 880-920 nm, etc. (see Govindjee 2004 for a review). In addition, measurement of the emission spectra under different excitations provides information about the major absorbing pigments in the samples. Here, we used the novel portable instrument for measuring low temperature $(77 \mathrm{~K})$ emission spectra described by Suggett et al. (2009, this Special Issue). Each of the collected samples was transferred to a GF/F filter in the laboratory and placed into the sample holder, which was cooled to the temperature of liquid nitrogen $(77 \mathrm{~K})$. Then, the sample was illuminated by narrow-band excitation provided by light-emitting diodes (LEDs). We used LEDs with maximum emission at 390, 455, 470, 505, 530 and $590 \mathrm{~nm}$. The emitted fluorescence signal was then collected, spectrally dispersed and detected in the spectral range of 190 to $1000 \mathrm{~nm}$. Proper care was taken to correct for instrument sensitivity and to subtract the instrument background signal. For sample preparation, we used a protocol similar to that of Suggett et al. (2009) with the following modifications: for plankton samples, we filtered $50 \mathrm{ml}$ of the water samples; the benthos samples of individual layers were stored in Eppendorf tubes that were vortexed before measurement and $250 \mu \mathrm{l}$ of the well-mixed suspension were poured and spread on GF/F filters. If the suspension contained large mineral particles, care was taken to evenly spread these across the filter.

Kinetic spectroscopy. We also used the room-temperature kinetic infrared fluorometric technique described by Koblížek et al. (2005) for quantification of oxygenic and anoxygenic phototrophs in the plankton samples. Here, plankton samples were directly analyzed in the measuring chamber of the instrument. The absolute concentrations of chl $a$ and bchl a were estimated from the amplitudes of the variable fluorescence (chl a variable fluorescence was measured in the 680-720 nm range, bchl $a$ in the spectral range $>820 \mathrm{~nm}$ ). The instrument was calibrated regularly against standard laboratory cultures with known pigment concentrations.

Microscopy and statistical analyses. A light microscope (Olympus BX51) with a digital camera (Olympus DP 70) was used to identify species and document species composition. Subsamples for diatom identification were prepared following methods described by Beneš et al. (2002) and mounted into the artificial resin pleurax. Frustules were observed using the Olympus BX51 
light microscope with differential interference contrast (DIC) and a scanning electron microscope (SEM JEOL 6380). Sample preparation for the SEM followed the protocol of Nebesářová (2002). Diatom taxa were identified according to the identification key used by Veselá (2006).

Species composition of microbial communities in the sampled ponds were compared using principal component analysis (PCA). The species data for the analysis were entered as presence/absence data. The analysis was performed using the program CANOCO (Ter Braak \& Šmilauer 1998) and an ordination diagram was created using CanoDraw software (Šmilauer 1992).

\section{RESULTS}

\section{Microscopic characterization of the planktonic and benthic phototrophic communities}

The samples were analyzed in parallel using optical microscopy and the fluorescence techniques. The planktonic communities invariably showed low species diversity. Phytoplankton of Ponds 61, 62, 63, 64, 103 and 200 was dominated by Nitzschia aff. N. lorenziana. In Ponds 63 and 200, this diatom was rather rare and heterotrophic flagellates accompanied it. Numerous single-celled rod-like bacteria dominated the plankton of Pond 201. At the highest salinity (Pond 304), Dunaliella salina was the sole phototroph encountered. Benthic communities were more diverse, with 9 to 32 different morphotypes of phototrophs. The oxygenic phototrophic microbial community of the salterns consisted of 26 species of diatoms, 14 species of Cyanobacteria, 2 green algae and 1 species of Chrysophyceae. An overall comparison of microbial community compositions of the ponds studied is provided as a PCA ordination diagram (Fig. 1).

\section{Spectroscopic analysis of planktonic microbial communities}

The low temperature emission spectra provide information about the presence and relative abundance of phototrophic microorganisms with distinct pigmentprotein complexes. Using blue (455 nm) excitation, the emission spectra of plankton from Ponds 61 to 64 were dominated by emission from PSII, with maxima at 685 and $695 \mathrm{~nm}$ (Fig. 2A), indicating that the community is dominated by oxygenic phototrophs. PSI emission (band with maximum at $\sim 715 \mathrm{~nm}$ ) characteristic of Cyanobacteria was observed only in plankton from Pond 63. Similarly, PBS emission (usually observed in the spectral region of 550-660 nm) was observed only in Pond 63 when appropriate excitation was used (530 nm, data not shown). The emission spectra of plankton from ponds with higher salinity confirmed the presence of oxygenic photosynthetic organisms in all studied ponds (Fig. 2B), with a maximum in the PSII region (681-687 $\mathrm{nm}$ ) and a shoulder at longer wavelengths that indicates the presence of some PSI (710 nm) emission. Spectroscopy detected oxygenic phototrophs even in Pond 103, where no organisms could be detected by microscopy. However, in these high-salinity ponds, the photosynthetic emission bands were always superimposed on a strong background emission of an unknown fluorophore. This background emission was excited only in the 450-510 nm spectral regions, i.e. within the absorption band of carotenoids. We noted that the intensity of this background emission increased with salinity, and in some cases, clear maxima could be observed at 575 and $620 \mathrm{~nm}$. The presence of a strongly absorbing carotenoid pigment was confirmed by absorption spectroscopy of particles in the high-salinity samples (S. Gehnke, unpubl. data).

In addition to oxygenic photosynthetic organisms, emission spectroscopy revealed the presence of photosynthetic bacteria containing bacteriochlorophylls. They were present in the plankton of all studied ponds, except for the crystallizer pond with the highest salinity (Pond 304). In emission spectra, 2 major bands were present, with maxima at 885 and $910 \mathrm{~nm}$ (Fig. 3A). These bands were preferentially excited by irradiance $>500 \mathrm{~nm}$ and are typical for bchl a-containing phototrophic bacteria. We assume that the different emission bands are characteristic of different bacterial species with different bacterial light-harvesting complexes. In each pond, one of the bands was dominant: the $885 \mathrm{~nm}$ band in Ponds 61, 63, 64 and 103, and the 915 nm emission band for bacteria in Ponds 62 and 201.

The fluorescence kinetics technique allowed us to estimate the absolute abundance of photosynthetic planktonic microorganisms in the studied ponds (Fig. 4A). The biomass of both the oxygenic and bacterial anoxygenic phototrophs was highest in ponds with a salinity of 60-120 $\mathrm{g} \mathrm{l}^{-1}$ (Ponds 61, 62, 64). The maximum chl a value was detected in Pond 62 (chl $a=$ $11.3 \mathrm{nM}$, salinity of $88 \mathrm{~g} \mathrm{l}^{-1}$ ), while the highest bchl $a$ concentration was observed in Pond 64 (bchl $a=$ $0.3 \mathrm{nM}$, salinity of $114 \mathrm{~g} \mathrm{l}^{-1}$ ). At higher salinities, the biomass of oxygenic phototrophs declined steeply with increasing salinity, but bchl a concentration remained high up to a salinity of $\sim 200 \mathrm{~g} \mathrm{l}^{-1}$. Only at the highest salt concentration (Pond 304, salinity of $329 \mathrm{~g} \mathrm{l}^{-1}$ ) no bchl a-containing phototrophs were detected. As a result, the relative molar ratio of bchl a/chl a was almost 1 at higher salinities of up to $200 \mathrm{~g} \mathrm{l}^{-1}$ (Fig. 4B). This is significantly higher than the usual ratios of bchl a/chl $a$ in oligotrophic seawater as determined by this 


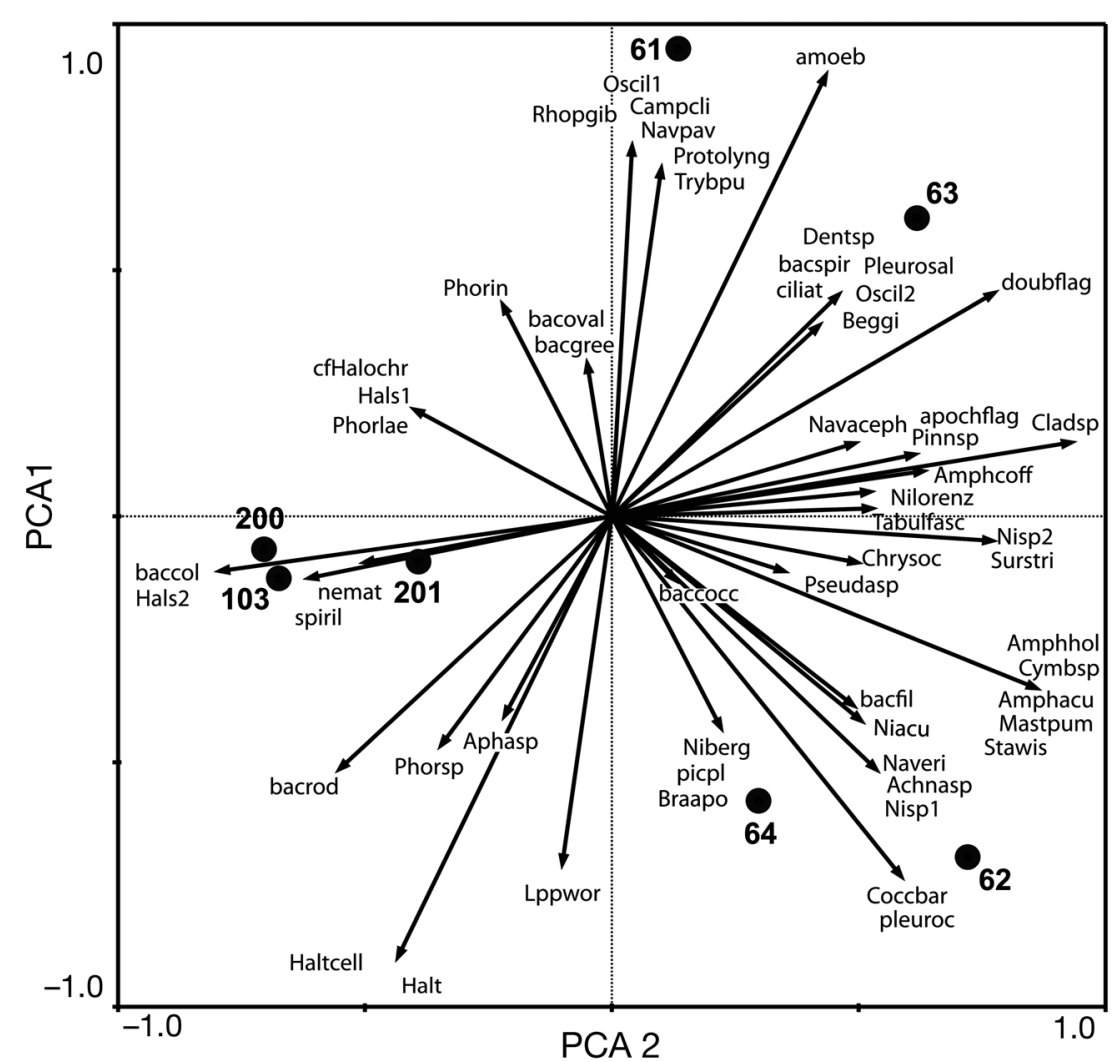

Fig. 1. Principal component analysis (PCA) describing the species composition of microbial communities in different saltern ponds. (๑) Sampling ponds. The first and second canonical axes together explain $46.7 \%$ of the total variability. Abbreviations are given below

$\begin{array}{ll}\text { apochflag } & \text { apochromatic flagellates } \\ \text { Lppwor } & \text { Leptolyngbya cf. woronichinii } \\ \text { Mastpum } & \text { Mastogloia pumilla } \\ \text { Navaceph } & \text { Navicula acephala } \\ \text { Naveri } & \text { Navicula cf. erifuga } \\ \text { Navpav } & \text { Navicula pavillardii } \\ \text { cfNavic } & \text { cf. Navicula } \\ \text { nemat } & \text { nematodes } \\ \text { Niacu } & \text { Nitzschia acula } \\ \text { Niberg } & \text { Nitzschia cf. bergii } \\ \text { Nilorenz } & \text { Nitzschia aff. N. lorenziana } \\ \text { Nisp1 } & \text { Nitzschia sp. 1 } \\ \text { Nisp2 } & \text { Nitzschia sp. 2 } \\ \text { Oscil1 } & \text { Oscillatoria margaritifera type 1 (thicker) } \\ \text { Oscil2 } & \text { Oscillatoria margaritifera type 1 (thinner) } \\ \text { Phorin } & \text { Phormidium cf. inundatum } \\ \text { Phorlae } & \text { Phormidium laetevirens } \\ \text { Phorsp } & \text { Phormidium sp. (thicker, bent tip) } \\ \text { picpl } & \text { single-celled spherical cyanobacterial } \\ & \text { picoplankton } \\ \text { pleuroc } & \text { unidentified pleurocapsacean cyano- } \\ & \text { bacterium } \\ \text { Pleurosal } & \text { Pleurosigma salinarum } \\ \text { Protolyng } & \text { Leptolyngbya subg. Protolyngbya sp. } \\ \text { Pseudasp } & \text { Pseudanabaena sp. } \\ \text { Rhopgib } & \text { Rhopalodia gibberula } \\ \text { spiril } & \text { Spirillum-like bacteria } \\ \text { Stawis } & \text { Stauroneis wislouchii } \\ \text { Surstri } & \text { Surirella striatula } \\ \text { Tabulfasc } & \text { Tabularia fasciculata } \\ \text { Trybpu } & \text { Tryblionella punctata } \\ & \end{array}$




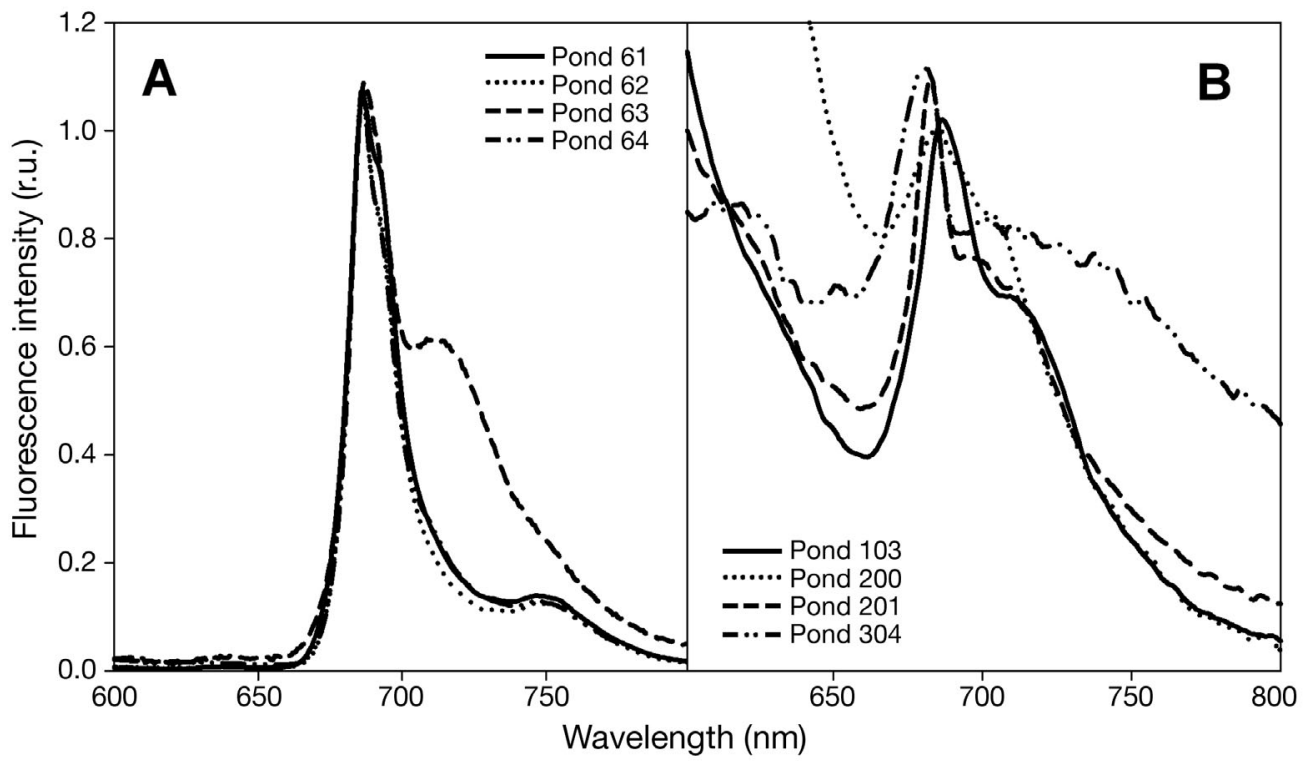

Fig. 2. Low temperature (77K) fluorescence emission spectra (intensity in relative units, r.u.) of oxygenic plankton in ponds with (A) low salinity (58-114 $\mathrm{g} \mathrm{l}^{-1}$ ) and (B) high salinity. Samples were excited by blue (455 $\mathrm{nm}$ ) excitation. Spectra were normalized to emission at $685 \mathrm{~nm}$. Note the increasing background signal in the high-salinity ponds

technique (bchl a/chl $a \sim 0.01$ in the Gulf of Aqaba, salinity of $40 \mathrm{~g} \mathrm{l}^{-1}$; H. Medová, unpubl. data). All of the ponds studied here can be classified as eutrophic based on phosphate concentrations (Table 1). Thus, the differences in bchl a/chl a ratios here as compared with that in the Gulf of Aqaba are likely due to differences in trophic conditions.

\section{Spectroscopic analysis of benthic microbial communities}

Spectroscopic studies were performed on the benthic communities from Ponds 62, 63, 64, 103, 200 and 201. The studied ponds differed from each other in the character of their sediments. Sediments of Ponds 62 to

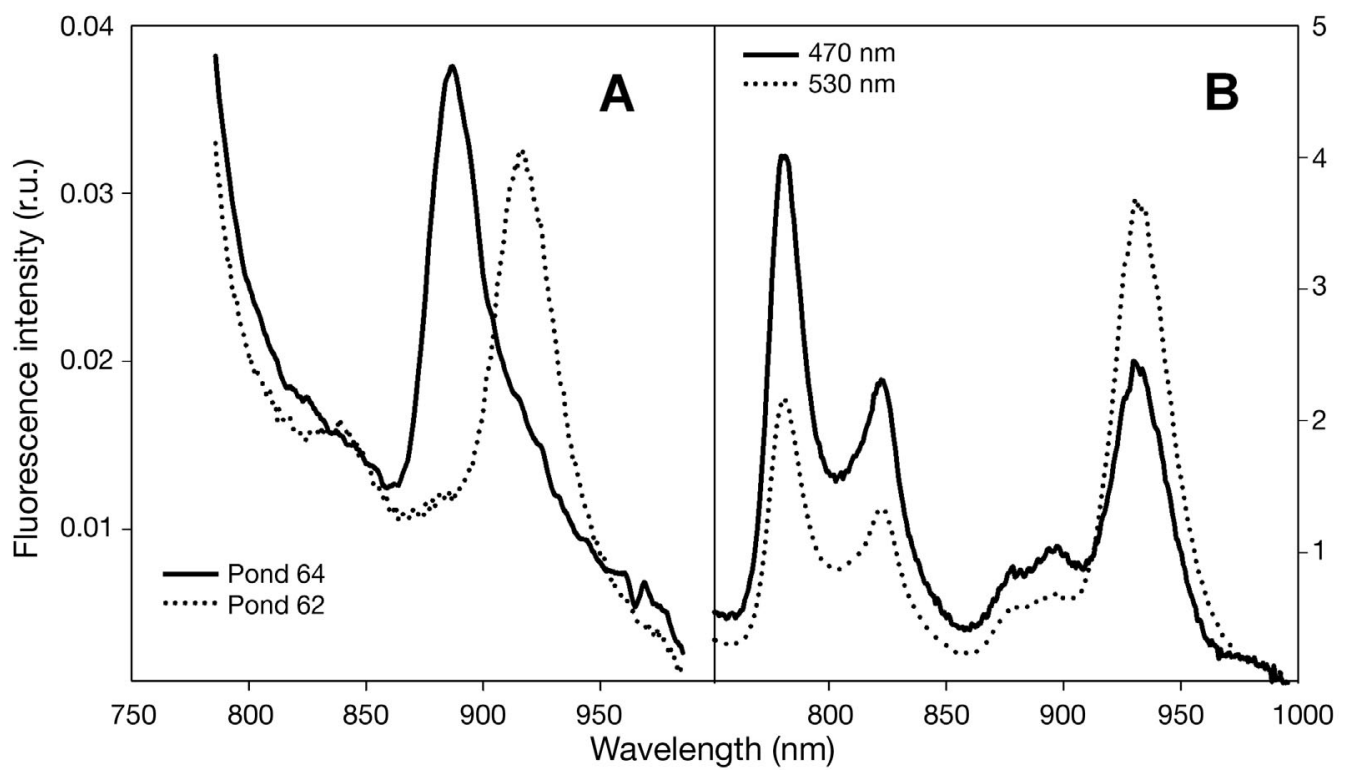

Fig. 3. Examples of $77 \mathrm{~K}$ fluorescence emission spectra of anoxygenic phototrophic bacteria. In the plankton of Ponds $61,63,64$ and 103, the spectra were dominated by a single emission band with a peak at $~ 885 \mathrm{~nm}$; in Ponds 62 and 201, the bacteria emitted with a maximum at $915 \mathrm{~nm}$. (A) shows representative spectra of Ponds 64 and 62, both of which were excited at $530 \mathrm{~nm}$. (B) Example of the complex spectra of samples from the benthos, obtained with the pink layer of sediment from Pond 200. Excitation dependence of the spectra reveals the presence of different light-harvesting pigments. Data in (A) and (B) are normalized to emission at $685 \mathrm{~nm}$ 

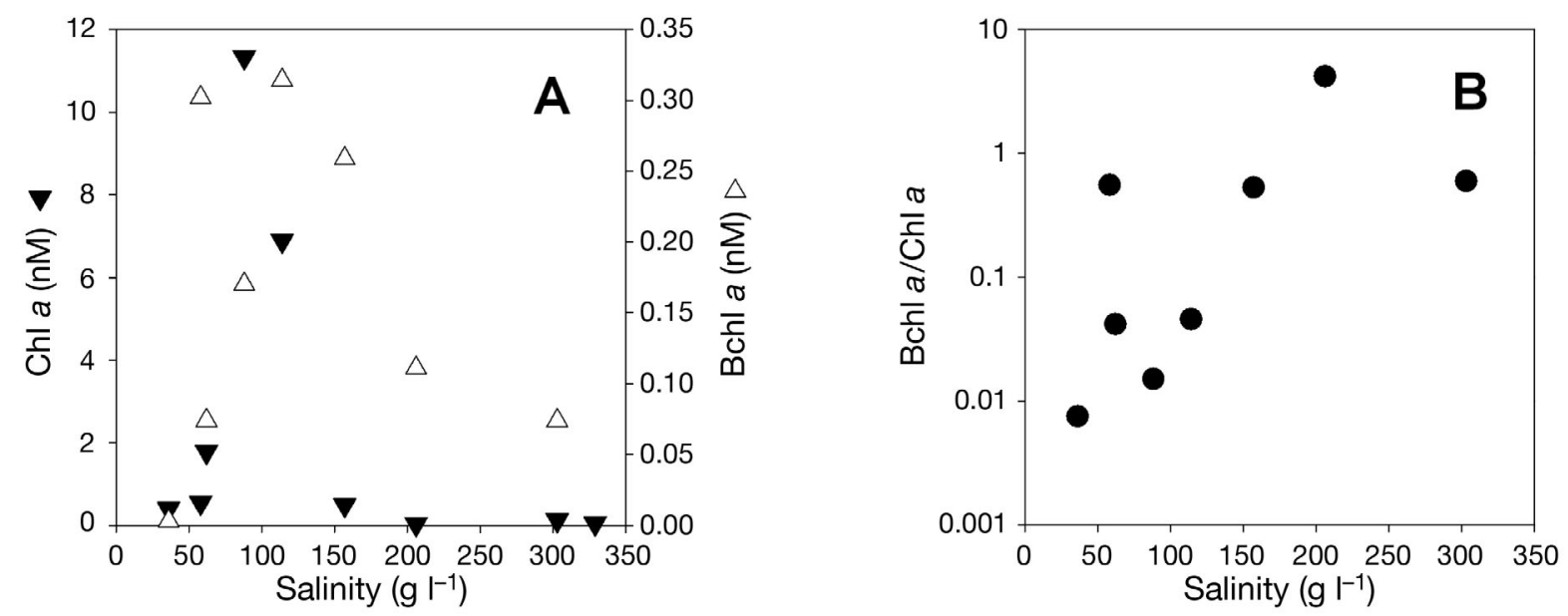

Fig. 4. (A) Concentration of oxygenic plankton (estimated as chl $a, \mathbf{\nabla}$ ) and anoxygenic phototrophic bacteria (estimated as bchl $a_{1}$ $\triangle$ ) as revealed by fluorescence kinetic spectroscopy. Also included in the graph are data for the oligotrophic Stn A in the Gulf of Aqaba, which was sampled during the same period. (B) Estimated ratio of anoxygenic to oxygenic pigment biomass as calculated from data in (A). Note the logarithmic scale

64 were muddy and their surfaces were covered with dense cyanobacterial mats. Gypsum crusts of various consistencies formed the bottoms of Ponds 103, 200 and 201. The spectroscopic data collected during analysis of the different sediment layers are summarized in Table 2 .

The sediment from Pond 62 (salinity of $88 \mathrm{~g} \mathrm{l}^{-1}$ ) had an upper layer containing Cyanobacteria (Halothece sp., Phormidium sp.), diatoms (Amphora acutiuscula, Navicula cf. vandamii, Nitzschia aff. N. lorenziana) and the green filamentous alga Cladophora sp. The communities of several lower layers $(0.25-3 \mathrm{~cm})$ consisted of the cyanobacterium Phormidium cf. inundatum, the diatoms Cymbella sp., Nitzschia aff. N. acula, cf. Navicula, and others. The 3-4 cm layer was characterized by the cyanobacterium Leptolyngbya cf. woronichinii and the diatoms Achnathes sp., Nitzschia sp. and Navicula cf. erifuga. Spectroscopy revealed the presence of benthic oxygenic and anoxygenic phototrophs in the upper $2 \mathrm{~cm}$. The dominant pigment complex of oxygenic benthic phototrophs was PSI with an emission

Table 1. Chemical parameters of water in the evaporation ponds

\begin{tabular}{|cccccc|}
\hline Pond & $\begin{array}{c}\mathrm{NO}_{2}{ }^{-} \\
\left(\mu \mathrm{mol} \mathrm{l}^{-1}\right)\end{array}$ & $\begin{array}{c}\mathrm{NO}_{3}{ }^{-} \\
\left(\mu \mathrm{mol} \mathrm{l}^{-1}\right)\end{array}$ & $\begin{array}{c}\mathrm{NH}_{4}{ }^{+} \\
\left(\mu \mathrm{mol} \mathrm{l}^{-1}\right)\end{array}$ & $\begin{array}{c}\mathrm{PO}_{4}{ }^{3-} \\
\left(\mu \mathrm{mol} \mathrm{l}^{-1}\right)\end{array}$ & $\begin{array}{c}\text { Salinity } \\
\left(\mathrm{g} \mathrm{l}^{-1}\right)\end{array}$ \\
\hline 61 & 0.33 & 3.65 & 1.13 & 4.26 & 62 \\
62 & 0.14 & 3.76 & 0.10 & 2.00 & 88 \\
63 & 0.36 & 3.14 & 46.70 & 2.02 & 58 \\
64 & 0.19 & 3.22 & 0.13 & 1.98 & 114 \\
103 & 0.18 & 3.75 & 0.23 & 3.54 & 157 \\
200 & 0.19 & 4.52 & 0.50 & 4.08 & 206 \\
201 & 0.47 & 7.16 & 0.30 & 6.58 & 303 \\
304 & 0.45 & 9.59 & 3.63 & 7.33 & 329 \\
\hline
\end{tabular}

maximum at $705 \mathrm{~nm}$. PSII formed only a shoulder band at $685 \mathrm{~nm}$, with an estimated PSI intensity of $20 \%$. No emission signals from PBS were detected, despite the fact that morphological observations revealed the presence of Cyanobacteria. The emission from anoxygenic phototrophic bacteria showed a major emission band with maxima at $\sim 917 \mathrm{~nm}$ (at $77 \mathrm{~K}, 890 \mathrm{~nm}$ at room temperature) and a smaller shoulder at $\sim 840 \mathrm{~nm}$. Additionally, we detected anoxygenic phototrophs with emission maxima at longer wavelengths (>975 nm) in the deeper parts of the sediment (from 1-4 cm depth).

The benthic phototrophic community from Pond 63 (salinity of $58 \mathrm{~g} \mathrm{l}^{-1}$ ) was characterized by Oscillatoria margaritifera as the dominant species in the top $2.5 \mathrm{~cm}$, accompanied by Phormidium cf. inundatum, Phormidium laetevirens, and diatoms (cf. Navicula, Pleurosigma salinarum, Amphora acutiuscula). Halochromatium-like purple sulfur bacteria were observed at 1.5-2.5 cm. Spectroscopy confirmed the taxonomic observations. Oxygenic phototrophs were detected down to a depth of $6.5 \mathrm{~cm}$ in the sediment. The PSI band was always dominant, with a maximum at 715-725 $\mathrm{nm}$ (depending on the wavelength of excitation). Only in the surface layers $(0.1-1.5 \mathrm{~cm})$ was the PSI signal accompanied by emission for PBS (maxima at 645 and $660 \mathrm{~nm})$. In the deeper layers, the PBS signal disappeared and PSI was accompanied by a new band with a maximum at $\sim 670 \mathrm{~nm}$. The signal of anoxygenic bacteria reflected the taxonomic diversity. In the surface layer, it was dominated by bands of purple bacteria at 910-920 nm, while addi- 
Table 2. Intensities (heights of the bands in arbitrary units after background subtraction) of individual emission bands of benthos samples of Ponds 62,63, 64, 103, 200 and 201. Based on their characteristic wavelengths, individual emission bands observed in the spectral range of 550-1000 nm (Band) were tentatively assigned to respective groups of phototrophic organisms (Assignment). Each of the assigned emission bands was excited by specific wavelengths (Excitation). The emission intensities were corrected for differences in the intensities of individual excitation light-emitting diodes (LEDs). Cyano: cyanobacteria; Oxygenic: oxygen evolving phototrophs; Chlorosomes: green bacteria; Purple: purple bacteria. Missing values: no peaks detected

\begin{tabular}{|c|c|c|c|c|c|c|c|c|c|c|c|}
\hline \multirow{3}{*}{$\begin{array}{l}\text { Band: } \\
\text { Assignment: } \\
\text { Excitation }(\mathrm{nm}):\end{array}$} & \multirow{3}{*}{$\begin{array}{l}\text { Background } \\
\text { Carotenoids } \\
470\end{array}$} & \multirow{3}{*}{$\begin{array}{l}\text { PBS 600- } \\
650 \\
\text { Cyano } \\
530\end{array}$} & \multirow{3}{*}{$\begin{array}{c}\text { B670 } \\
\text { PSII? } \\
530\end{array}$} & $\begin{array}{c}\text { PSI } 705- \\
725\end{array}$ & $\begin{array}{c}\text { PSII } 680- \\
\quad 695\end{array}$ & \multirow{2}{*}{\multicolumn{2}{|c|}{$\begin{array}{cc}\text { B780- } & \text { B820- } \\
800 & 850 \\
- \text { Chlorosomes- }\end{array}$}} & \multirow{3}{*}{$\begin{array}{l}\text { B880- } \\
890 \\
530\end{array}$} & \multirow{2}{*}{\multicolumn{2}{|c|}{$\begin{array}{c}\text { B910- } \text { B930- } \\
920 \quad 950 \\
\text { Purple }\end{array}$}} & \multirow[t]{2}{*}{ B975 } \\
\hline & & & & \multirow{2}{*}{\multicolumn{2}{|c|}{ - Oxygenic -}} & & & & & & \\
\hline & & & & & 455 & \multicolumn{2}{|c|}{$530 \quad 530$} & & 530 & 530 & 470 \\
\hline \multicolumn{12}{|c|}{ Sediment depth (cm) } \\
\hline \multicolumn{12}{|c|}{ Pond 62} \\
\hline $0.0-0.25$ & & & & 5600 & & & & & 917 & & \\
\hline $0.25-1.0$ & & & & 1600 & & & & & 150 & & 50 \\
\hline $1.0-1.5$ & & & & 1500 & & & & & 130 & & 150 \\
\hline $1.5-2.0$ & & & & 1200 & 120 & & & & 80 & & 150 \\
\hline $2.0-3.0$ & & & & 150 & 10 & & & & 90 & & \\
\hline $3.0-4.0$ & & & & 140 & & & & & & & 90 \\
\hline $4.0-5.0$ & & & & & & & & & & & 25 \\
\hline \multicolumn{12}{|l|}{ Pond 63} \\
\hline $0.1-0.5$ & & 1500 & & 650 & & & & & 60 & & \\
\hline $0.5-1.5$ & & 400 & & 1700 & & & & & 10 & & 70 \\
\hline $1.5-2.5$ & & & & 1400 & & 100 & & & 60 & & 120 \\
\hline $2.5-3.5$ & & & 60 & 700 & & 40 & & & 60 & & 30 \\
\hline $3.5-4.5$ & & & 30 & 180 & & & & & 20 & & \\
\hline $4.5-5.5$ & & & 40 & 140 & & & & & 15 & & \\
\hline $5.5-6.5$ & & & 30 & 100 & & & & & & & \\
\hline $5.0-6.0$ & & & & & & & & & & & \\
\hline \multicolumn{12}{|l|}{ Pond 64} \\
\hline $0.0-0.2$ & & 180 & & 850 & 1600 & & 30 & & 100 & & \\
\hline $0.2-0.5$ & & 220 & & 2700 & 600 & & 30 & & 160 & & 40 \\
\hline $0.5-1.0$ & & 180 & & 800 & 200 & & 20 & & 120 & & \\
\hline $1.0-2.0$ & & 200 & & 900 & 150 & & & & 120 & & \\
\hline $2.0-3.0$ & & 120 & & 230 & 90 & & 10 & & 80 & & \\
\hline $3.0-4.0$ & & 100 & & 120 & 30 & & 5 & & 30 & & 70 \\
\hline $4.0-5.0$ & & 90 & & 70 & 10 & & & & 15 & & 80 \\
\hline \multicolumn{12}{|l|}{ Pond 103} \\
\hline $0.0-0.2$ & 200 & & & 1400 & 780 & 50 & & 50 & & 80 & \\
\hline $0.2-0.3$ & 203 & 1400 & & 7500 & 1200 & 150 & & 80 & & 60 & \\
\hline $0.3-0.4$ & 205 & 400 & & 760 & 320 & 150 & & 760 & & 1000 & \\
\hline $0.4-0.5$ & 300 & 3000 & & 2500 & 900 & & 100 & & & 560 & \\
\hline $0.5-1.0$ & 200 & 700 & & 2600 & 800 & 200 & 100 & 100 & & 540 & \\
\hline $1.0-2.0$ & 200 & 180 & 400 & 480 & & 70 & & 100 & & 250 & \\
\hline $2.0-3.0$ & 300 & & 110 & 300 & & 50 & & 120 & & 250 & \\
\hline $3.0-4.5$ & 220 & & 120 & 250 & & 60 & & 50 & & 80 & \\
\hline Pond 200 & & & & & & & & & & & \\
\hline $0.0-0.5$ & 400 & 400 & & 4200 & 1200 & 80 & & 120 & & & 60 \\
\hline $0.5-1.0$ & 100 & 50 & & 1350 & 470 & 50 & & 20 & & & 30 \\
\hline $1.0-1.5$ & 250 & & & 1000 & 470 & & & 20 & & & 40 \\
\hline $1.5-2.0$ & 210 & 350 & & 510 & 210 & 40 & & 30 & & 160 & 20 \\
\hline $2.0-2.5$ & 120 & 350 & 1650 & 750 & & 1000 & 600 & 300 & & 1710 & \\
\hline $2.5-3.0$ & 450 & 300 & 300 & 570 & & 220 & 120 & 150 & & 440 & \\
\hline $3.0-3.5$ & 350 & & 120 & 160 & & 60 & 35 & 40 & & 90 & \\
\hline $3.5-4.0$ & 370 & & 170 & 150 & & 100 & & 50 & & 40 & \\
\hline $4.0-4.5$ & 250 & & 90 & 150 & & 50 & & 50 & & 70 & \\
\hline $4.5-5.0$ & 250 & & 60 & 60 & & 80 & & 60 & & 90 & \\
\hline Pond 201 & & & & & & & & & & & \\
\hline $0.0-0.5$ & 250 & & & 600 & 850 & & & & 25 & & \\
\hline $0.5-1.0$ & 270 & 250 & & 800 & 420 & & & & 30 & & \\
\hline $1.0-1.5$ & 280 & 230 & & 350 & 175 & & & & 400 & & \\
\hline $1.5-2.0$ & 300 & 1800 & & 2300 & 400 & & & & 200 & & \\
\hline $2.0-2.5$ & 400 & & & 270 & 30 & & & & 3100 & & \\
\hline $2.5-3.0$ & 470 & 280 & & 350 & 100 & & & & 315 & & \\
\hline $3.0-3.5$ & 300 & 70 & & 120 & & & & & 45 & & \\
\hline
\end{tabular}


tional bands with maxima at $~ 800$ and $>975 \mathrm{~nm}$ were observed in deeper layers.

In Pond 64 (salinity of $114 \mathrm{~g} \mathrm{l}^{-1}$ ), the upper sediment layers were characterized by the Cyanobacteria Leptolyngbya cf. woronichinii and Halothece sp. and the diatoms cf. Navicula, Mastogloia pumila, Achnanthes sp., Amphora spp., Cocconeis bardawilensis, Nitzschia aff. N. lorenziana, and Nitzschia aff. N. acula. The deeper layers $(2-5 \mathrm{~cm})$ contained a Gomphosphaerialike cyanobacterium, an unidentified pleurocapsacean cyanobacterium and dying filaments of Cladophora sp. In the surface layer $(0-0.2 \mathrm{~cm})$, the emission signal was dominated by PSII bands at 685 and $695 \mathrm{~nm}$. PSI emission formed only a shoulder band with a maximum at $720 \mathrm{~nm}$. In the deeper layers (down to $2 \mathrm{~cm}$ ), PSI dominated the signal and the ratio of PSI/PSII band intensities gradually increased from 2 to 4 . PBS had only a minor contribution that decreased with depth. In the deepest layers where oxygenic photosynthesis could still be observed $(4-5 \mathrm{~cm})$, the remaining oxygenic phototrophs only had a chl a-containing antenna. Interestingly, in deeper layers, a strong emission band from PBS was observed at $\sim 650 \mathrm{~nm}$. The anoxygenic bacteria showed mostly a single dominant emission band at $920 \mathrm{~nm}$ and a shoulder at $850 \mathrm{~nm}$. In addition, some bacteria with long-wavelength emission maxima were present in the subsurface layer and in the deepest layers $(>3 \mathrm{~cm})$.

Pond 103 (salinity of $157 \mathrm{~g} \mathrm{l}^{-1}$ ) had colonial and single-celled Halothece sp., Halospirulina tapeticola, Leptolyngbya cf. woronichinii, and Phormidium sp. in the upper layer $(0-1 \mathrm{~cm})$. The middle layers $(1-3 \mathrm{~cm})$ were colonized mainly by Cyanobacteria (cf. Leptolyngbya, Phormidium cf. inundatum) and by the diatom Nitzschia aff. $N$. lorenziana. The deepest layer $(3-4.5 \mathrm{~cm})$ showed the presence of Cyanobacteria (Aphanocapsa sp., Pseudanabaena sp., Phormidium laetevirens), together with the diatoms Amphora coffeaeformis and Nitzschia aff. N. acula. The emission spectra of samples from the crust (top $0.4 \mathrm{~cm}$ of this gypsum sediment) showed the presence of oxygenic phototrophs with pronounced PSI emission at $\sim 720 \mathrm{~nm}$ and only a minor signal for PBS (650 and $665 \mathrm{~nm}$ ). The PSI emission was almost $7 \times$ higher than that of PSII. There were abundant anoxygenic phototrophs in the crust, with bands at 930, 886 and $780 \mathrm{~nm}$. In the pink layer $(0.3-0.4 \mathrm{~cm})$ of the crust, the $886 \mathrm{~nm}$ emission was twice as intense as the PSI band (when both were excited at $455 \mathrm{~nm}$; data not shown).

Spectra revealed that samples from $0.4-1 \mathrm{~cm}$ in the sediment were dominated by the PSI signal at $720 \mathrm{~nm}$, and the PBS signal at $650 \mathrm{~nm}$ was most pronounced only in the thin $0.4-0.5 \mathrm{~cm}$ layer. Anoxygenic bacteria showed a peak at $945 \mathrm{~nm}$ with minor bands at $~ 850$ and $810 \mathrm{~nm}$. Chlorosome emission at $770 \mathrm{~nm}$ was observed in the green layer at $0.5-1 \mathrm{~cm}$ depth. In the deeper layers $(1-4.5 \mathrm{~cm})$, the emission from oxygenic PSI was less pronounced because of a strong background emission signal similar to that described above for planktonic samples; usually, this signal was structured into bands with maxima at $\sim 575$ and $620 \mathrm{~nm}$. The anoxygenic bacteria emitted at 2 bands: 885 and $935 \mathrm{~nm}$.

In Pond 200 (salinity of $206 \mathrm{~g} \mathrm{l}^{-1}$ ), the upper layers $(0-2 \mathrm{~cm})$ were colonized mainly by the Cyanobacteria Halothece sp., Leptolynbya cf. woronichinii and Phormidium laetevirens. The deeper layers (1.5$2.5 \mathrm{~cm}$ ) contained the Cyanobacteria Halospirlina tapeticola (both thin and thick types), cf. Leptolyngbya, Phormidium cf. inundatum, and Phormidium sp. Below was a layer colonized by the single-celled cyanobacterium Halothece sp. together with the purple sulfur bacterium Halochromatium sp. Spectroscopy confirmed the presence of oxygenic phototrophs in all layers. Cyanobacteria with a characteristic PSI band were dominant in the top layers down to $2 \mathrm{~cm}$. While PSII emitted at $685 \mathrm{~nm}$ in these top layers, we observed a gradual shift of this emission band to $670 \mathrm{~nm}$ in the deeper layers. PBS were clearly present only in the top layer. In all layers, the emission spectra contained the above described background signal with maxima at 575 and $620 \mathrm{~nm}$. According to the spectral signatures, several classes of anoxygenic bacteria were present. In the top 2 layers $(0-1 \mathrm{~cm})$, there were bacteria with emission maxima at $\sim 890 \mathrm{~nm}$ and some with a longwavelength maximum at $>975 \mathrm{~nm}$. The composition of the anoxygenic biomass changed significantly at layer $4(1.5-2.0 \mathrm{~cm})$, where a strong emission band at $930 \mathrm{~nm}$ was observed (Fig. 3B). This band was accompanied by a broad shoulder down to $870 \mathrm{~nm}$. Further analysis of it by deconvolution into Gaussian curves suggested that it consisted of 2 bands peaking at $~ 875$ and $895 \mathrm{~nm}$. The layer at $2.0-2.5 \mathrm{~cm}$ was dominated by green bacteria containing chlorosomes (emission at 780 and $820 \mathrm{~nm}$ ). Microscopic observation revealed the presence of rather big ovoid Halochromatium-like purple sulfur bacteria in this layer. At all deeper layers, bacteria emitting at $930 \mathrm{~nm}$ with a shoulder at $890 \mathrm{~nm}$ were still detected. Chlorosome-containing green bacteria were also present in the deeper layers.

Generally, main bacterial emission bands from the sediments obtained from Ponds 103 (salinity of $157 \mathrm{~g}$ $\mathrm{l}^{-1}$ ) and 200 (salinity of $206 \mathrm{~g} \mathrm{l}^{-1}$ ) could be divided into 6 spectral groups. These comprised bands centered approximately at $875,885,895,905$ and $930 \mathrm{~nm}$ and a putative emission band peaking at $>970 \mathrm{~nm}$ (Fig. 5). While these bands were not resolved equally well in different layers, their presence was often revealed by deconvolution of the spectrum into a sum of Gaussian curves. In most layers, at least 2 of the bands were detected. 
The sediment layers from Pond 201 (salinity of $303 \mathrm{~g}$ $\mathrm{l}^{-1}$ ) could be divided into 4 groups according to their species composition. The uppermost layer $(0-0.5 \mathrm{~cm})$ was characterized by the cyanobacterium Leptolyngbya cf. woronichinii and single-celled Halothece sp. Layers 2 and $3(0.5-1.5 \mathrm{~cm})$ contained the cyanobacteria Phormidium cf. inundatum and single-celled Halothece sp., the diatom Nitzschia aff. N. lorenziana, and the chrysophycean alga cf. Chrysococcus. Layers 4 and $5(1.5-2.5 \mathrm{~cm})$ mainly contained the colonial cyanobacterium Halothece sp., together with Phormidium cf. inundatum. Unlike the oxygenic phototrophs in the deeper layers $(0.5-2.0 \mathrm{~cm})$ with pronounced emission maxima for PSI, the organisms in the top, orangecolored layer had maximum emission at $685 \mathrm{~nm}$ (PSII). The strongest PSI signal was observed in the greencolored layer $(1.5-2.0 \mathrm{~cm})$. The diversity of pigmentprotein complexes of the anoxygenic bacteria was minimal. Throughout all layers, we detected only bacteria with an emission maximum between 905 and $910 \mathrm{~nm}$.

\section{DISCUSSION}

The evaporation ponds represent a wide variety of salinities, ranging from 58 to $329 \mathrm{~g} \mathrm{l}^{-1}$. A high diversity of Cyanobacteria, diatoms, green algae and anoxygenic phototrophic bacteria was observed.

With the exception of recent works of Bachar et al. (2008) and Kühl \& Polerecky (2008), no studies were

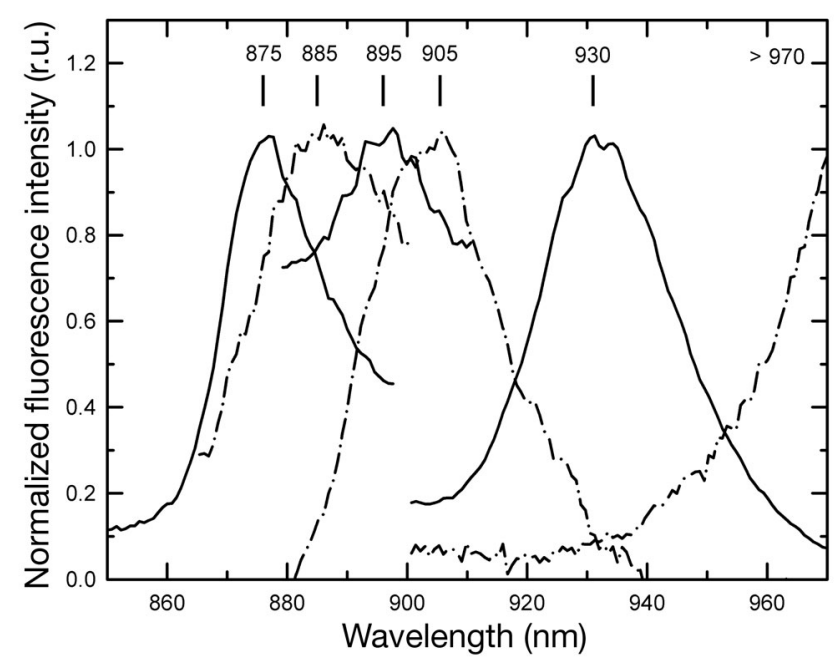

Fig. 5. Main emission bands of purple bacteria from Ponds 103 and 200. Peaks are labelled with their respective emission spectra. Note that the peak with a maximum at $~ 930 \mathrm{~nm}$ was also present in the spectra labeled 875, 885 and 895. This band was deleted for clarity of presentation, as was the $875 \mathrm{~nm}$ shoulder in the spectrum labeled 895. Spectra labeled 875 and 885 were detected in Pond 103, while the rest were from Pond 200. Spectra were normalized to the intensity (in relative units, r.u.) of the labeled bands performed in which spectroscopic techniques such as emission spectroscopy and kinetic fluorometry were applied to natural communities of halophilic and halotolerant benthic and planktonic phototrophs. Spectroscopic data in the low-oxygen layers showed the presence of both green and purple photosynthetic bacteria. The former were identified by the simultaneous presence of emission bands at $\sim 780 \mathrm{~nm}$ (bchl $\mathrm{c}$ ) and $820 \mathrm{~nm}$ (bchl a), which originate from chlorosomes (see van de Meene et al. 2007 for spectra of both green sulfur and filamentous bacteria). Two groups of anoxygenic phototrophs are known to use chlorosomes for light harvesting: green sulfur bacteria (Chlorobi) and green filamentous bacteria (Chloroflexi). As shown by Schmidt \& Trissl $(1998 a, b)$ and recently by van de Meene et al. (2007), the chlorosome emission of both groups is very similar; however, they differ by the presence of an emission band at $\sim 900 \mathrm{~nm}$, which is present only in Chloroflexi and originates from the inner LH1-type of light-harvesting complex similar to the inner antenna of purple bacteria. Members of this group have recently been found in hypersaline environments (Klappenbach \& Pierson 2004, Bachar et al. 2008). However, we were unable to find a convincing correlation between the intensity of chlorosome emission and the intensity of any of the emission bands located in the $>870 \mathrm{~nm}$ region; thus, we were unable to unambiguously decide on the type of green bacteria present in our samples.

As shown in Fig. 5, at least 6 spectral bands can be distinguished in the $870-1000 \mathrm{~nm}$ region of the emission spectra. Since emission of the bchl a-containing pigment-protein complexes can reach well above $1020 \mathrm{~nm}$ under cryogenic temperatures (Permentier et al. 2001), one can assume that the bands lying above $870 \mathrm{~nm}$ pertain to bchl a. because the high efficiency of LH2 to LH1 energy transfer prevents the external antenna from contributing significantly to the emission spectrum even in species that contain external (LH2/LH3) antenna complexes, we suggest that all bands in Fig. 5 belong to inner antenna, LH1. This suggests the presence of at least 6 different bacterial species, although an attempt at more detailed taxonomic assignment based solely on spectroscopic data is not tenable.

The division of the phototrophic microorganisms into 3 functional groups according to their emission spectra (oxygenic phototrophs containing PSI and PSII, green bacteria containing chlorosomes and purple bacteria containing LH1) allowed us to semi-quantitatively compare the vertical distribution of phototrophs in the benthos of the studied ponds (Fig. 6). In general, the quantity of oxygenic phototrophs in all ponds decreased exponentially with depth, confirming the dependence of their abundance on irradiance levels 
and oxygen availability. Oxygenic phototrophs with a dominant PSI signal were observed as deep as $5 \mathrm{~cm}$ below the surface. In Ponds 62, 63 and 64, no green anoxygenic bacteria were observed; only purple bacteria were seen, and their abundance also decreased with depth down to $5 \mathrm{~cm}$ (with the exception of Pond 63, where maximum abundances were observed $2 \mathrm{~cm}$ below the surface). Significantly higher abundances of anoxygenic bacterial phototrophs (both green and purple) were observed in the well-structured benthic layers in high-salinity Ponds 103, 200 and 201. Green bacteria formed a significant fraction of the emission signal (and thus of the community) only in Ponds 103 and 200. The data shown in Table 2 and plotted in Fig. 6 also allowed us to roughly estimate the relative contribution of the oxygenic and anoxygenic phototrophs. While anoxygenic bacteria formed only a minor part of the community in the surface layers of Ponds 62 and 63, they clearly dominated over oxygenic phototrophs $(\sim 30 \times$ in the $2.0-2.5 \mathrm{~cm}$ layer of Pond 201) in the deeper layers of the high-salinity crusts.

In some of the deeper $(>1 \mathrm{~cm})$ layers, we observed an emission band with a maximum at $\sim 670 \mathrm{~nm}$. Since this band substituted the classical emission band of PSII at

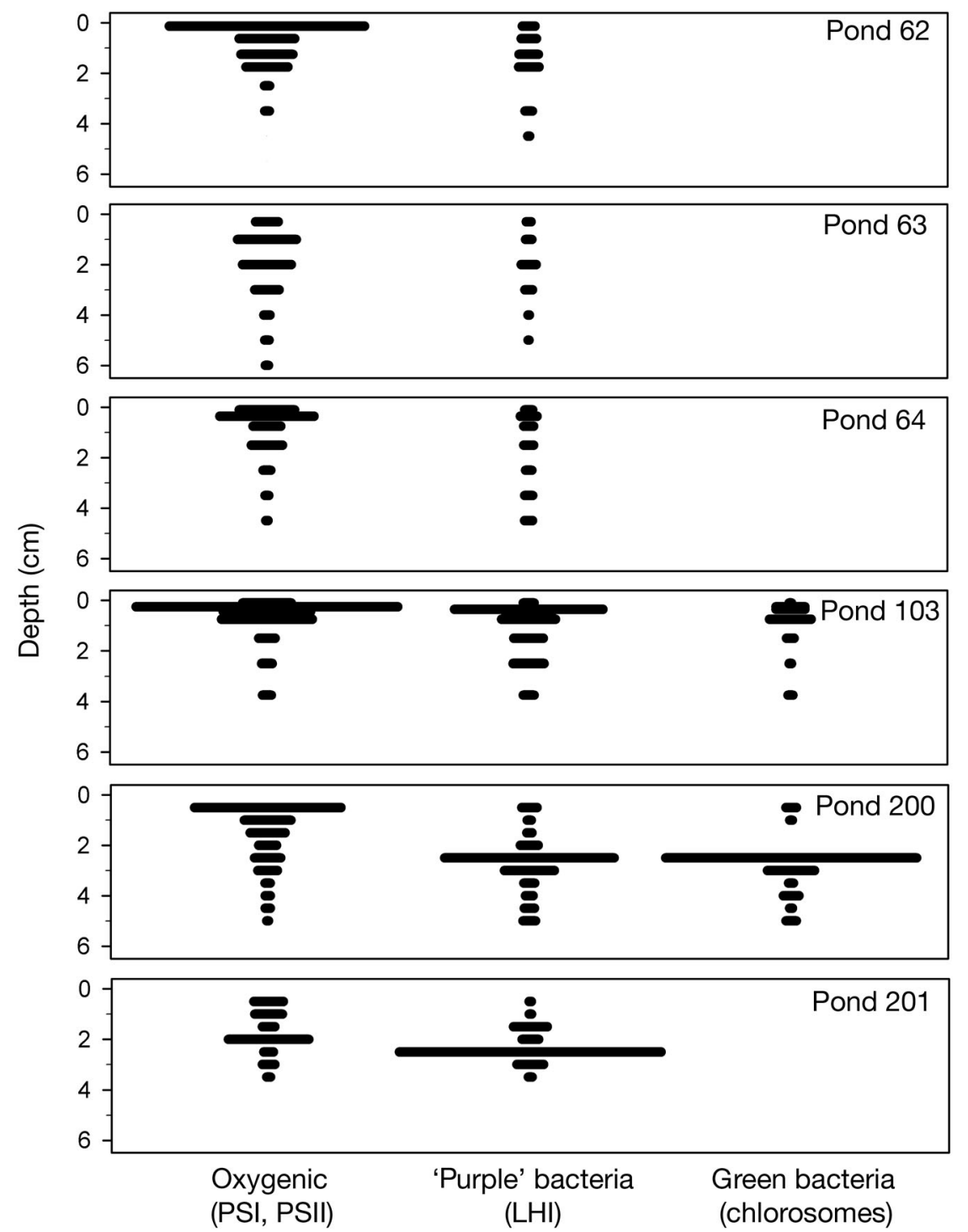

Fig. 6. Graphic presentation of spectroscopic data from Table 2, showing the vertical distribution of the main types of photosynthetic organisms within the benthos. The emission bands were grouped according to their pertinence to the main groups of phototrophic organisms: oxygenic phototrophs (PSI and PSII), purple bacteria (all groups containing LH1 antenna, including aerobic anoxygenic bacteria) and green bacteria (containing chlorosomes). The widths of the bars denote normalized intensities of respective emission bands. For each of the 3 spectral groups, the longest bar denotes the layer with the highest abundance of a given type of phototrophs among all ponds (corresponds to 1 after normalization) 
$685 \mathrm{~nm}$ (we never observed both bands simultaneously in the same spectrum), we speculate that this represents some form of PSII that is modified under the microanaerobic and dark conditions in the deeper benthos. A band at a similar position has been observed in etiolated higher plants and was assigned to the presence of protochlorophyll etioplasts (Boddi et al. 1993). A second peculiarity was the background signal that was always observed in samples from higher salinities, both in the benthos and in the plankton (see e.g. Fig 2B and Table 2, column 'Background'). This signal often had discernible maxima at 575 and $620 \mathrm{~nm}$. It is of unknown origin and we can only speculate that it might come from some forms of carotenoids (retinal, salinixanthin, $\beta$-carotene) that are known to accumulate at higher salinities. This would be supported by the fact that the band is preferably excited by wavelengths 450-500 nm. Alternatively, it might be emitted by some inorganic fluorophore that is contained in the highly concentrated brines. Further experiments are necessary to understand this phenomenon.

Planktonic communities of the investigated ponds were far less diverse than the benthic mats. Diatoms were most frequently encountered in our microscopic survey. The spectroscopy technique revealed the presence of anoxygenic purple phototrophic bacteria in all ponds studied (with the exception of the most saline pond, 304). These planktonic anoxygenic bacteria were aerobic, since we detected levels of oxygen that were at or above saturation (data not shown) in all ponds (except for Pond 304), indicating that the observed phototrophs belonged to aerobic anoxygenic phototrophic (AAP) bacteria. AAP bacteria are a group of phototrophic organisms that depend mostly on heterotrophic metabolism, but are capable of utilizing light as an auxiliary source of energy (Koblížek et al. 2003, Yurkov \& Csotonyi 2009). The AAP, as judged by their emission spectra, showed only a limited diversity, but formed a progressively increasing fraction of the community as the salinity of the environment increased, confirming their tolerance to extreme environments (Yurkov \& Csotonyi 2003, 2009). The very high bacterial abundances in Ponds 63 and 61 (with salinity of $\sim 60 \mathrm{~g} \mathrm{l}^{-1}$ ) is probably related to the high organic and nutrient content of these shallow and wellmixed ponds, which are optimal conditions for photoheterotrophic metabolism.

The present study shows that classical microscopy and modern spectroscopic techniques complement each other well and that their combination can provide new information on the structure and photophysiology of both planktonic and benthic communities of phototrophs in natural ecosystems over a wide range of salt concentrations. Application of spectroscopy allowed the first documentation of increasing amounts of bchl $a$ with increasing salinity in the plankton of the salterns. The massive occurrence of chlorosome-containing green anoxygenic phototrophic bacteria in the benthic mats at salinities exceeding $150 \mathrm{~g} \mathrm{l}^{-1}$, as detected here using emission spectroscopy, has also not been reported before. The organisms that harbor these pigments now deserve further in-depth study. Emission spectroscopy also supported the microscopic observation of viable autophototrophs in deeper sediment layers, which might be considered an artifact without this proof. Spectroscopy also revealed the presence of an unknown fluorophore that is present at high salt concentrations.

Acknowledgements. We thank the Israel Salt Company in Eilat, Israel for allowing access to the salterns and Y. Blumenfeld for technical assistance and measurements of oxygen concentration in the ponds. We also thank the Batsheva de Rothschild Foundation, Bar Ilan University, the Moshe Shilo Center for Marine Biogeochemistry, and the staff of the Interuniversity Institute for funding and logistic support. The Program Support of Targeted Research in the Academy of Sciences of CR projects no. 1QS600170504 and 1QS500200570 (O.P.) provided financial assistance for this study. K.R. and E.Z. were supported by projects GA ASCR AV0Z6017517 and The Grant Agency of the Czech Republic project no. 206/06/0462. The research of O.P. and H.M. was also supported by institutional support concepts AV0Z50200510 and MSM6007665808. This study was conducted during the 8th International Workshop of the Group for Aquatic Primary Productivity (GAP) and the Batsheva de Rothschild Seminar on Gross and Net Primary Productivity held at the Interuniversity Institute for Marine Sciences, Eilat, Israel in April 2008.

\section{LITERATURE CITED}

Bachar A, Polerecky L, Fischer JP, Vamvakopoulos K, de Beer D, Jonkers HM (2008) Two-dimensional mapping of photopigment distribution and activity of Chloroflexus-like bacteria in a hypersaline microbial mat. FEMS Microbiol Ecol 65:434-448

Beneš J, Kaštovský J, Kočárová R, Kočár P, Kubečková K, Pokorný P, Starec P (2002) Archaeobotany of the Old Prague Town defence system, Czech Republic: archaeology, macro-remains, pollen, and diatoms. Veg Hist Archaeobot 11:107-119

Boddi B, Ryberg M, Sundqvist C (1993) Analysis of the 77-K fluorescence emission and excitation spectra of isolated etioplast inner membranes. J Photochem Photobiol B 21: 125-133

> Caumette P, Matheron R, Raymond N, Relexans JC (1994) Microbial mats in the hypersaline ponds of Mediterranean salterns (Salins-de-Giraud, France). FEMS Microbiol Ecol 13:273-286

Cornée A (1982) Bactéries des saumures et des sédiments des marais salants de Salin-de-Giraud (Sud de la France). Géol Mediterr 9:369-389

Govindjee (2004) Chlorophyll a fluorescence: a bit of basics and history. In: Papageorgiou GC, Govindjee (eds) Chlorophyll fluorescence: a signature of photosynthesis Kluwer Academic Publishers, Dordrecht, p 1-42 
Ionescu D, Lipski A, Altendorf K, Oren A (2007) Characterization of the endoevaporitic microbial communities in a hypersaline gypsum crust by fatty acid analysis. Hydrobiologia 576:15-26

Klappenbach JA, Pierson BK (2004) Phylogenetic and physiological characterization of a filamentous anoxygenic photoautotrophic bacterium 'Candidatus Chlorothrix halophila' gen. nov., sp. nov., recovered from hypersaline microbial mats. Arch Microbiol 181:17-25

Koblížek M, Béjà O, Bidigare RR, Christensen S and others (2003) Isolation and characterization of Erythrobacter sp. strains from the upper ocean. Arch Microbiol 180:327-338

Koblížek M, Ston-Egiert J, Sagan S, Kolber Z (2005) Diel changes in bacteriochlorophyll a concentration suggest rapid bacterioplankton cycling in the Baltic Sea. FEMS Microbiol Ecol 51:353-361

Kühl M, Polerecky L (2008) Functional and structural imaging of phototrophic microbial communities and symbioses. Aquat Microb Ecol 53:99-118

Nebesářová J (2002) Elektronová mikroskopie pro biology. Multimediální učební texty (Multimedia learning text), www.paru.cas.cz/lem/book/index.html

Oren A (2009) Saltern evaporation ponds as model systems for the study of primary production processes under hypersaline conditions. Aquat Microb Ecol 56:193-204

Oren A, Sørensen KB, Canfield DE, Teske AP, Ionescu D, Lipski A, Altendorf K (2009) Microbial communities and processes within a hypersaline gypsum crust in a saltern evaporation pond (Eilat, Israel). Hydrobiologia 626:15-26

Permentier HP, Neerken S, Overmann J, Amesz J (2001) A bacteriochlorophyll a antenna complex from purple bacteria absorbing at $963 \mathrm{~nm}$. Biochemistry 40:5573-5578

Schmidt KA, Trissl HW (1998a) Combined fluorescence and photovoltage studies on chlorosome containing bacteria I. Whole cells of Chloroflexus aurantiacus. Photosynth Res 58:43-55

Schmidt KA, Trissl HW (1998b) Combined fluorescence and photovoltage studies on chlorosome containing bacteria II. Whole cells and chlorosome-depleted membranes of Chlorobium limicola. Photosynth Res 58:57-70

Editorial responsibility: Ilana Berman-Frank, Ramat Gan, Israel
Šmilauer P (1992) CANODRAW Users guide v. 3.0. Microcomputer Power, Ithaca, New York

Sørensen KB, Canfield DE, Oren A (2004) Salt responses of benthic microbial communities in a solar saltern (Eilat, Israel). Appl Environ Microbiol 70:1608-1616

Sørensen KB, Canfield DE, Teske AP, Oren A (2005) Community composition of a hypersaline endoevaporitic microbial mat. Appl Environ Microbiol 71:7352-7365

> Sørensen K, Reháková K, Zapomělová E, Oren A (2009) Distribution of benthic phototrophs, sulfate reducers, and methanogens in two adjacent saltern evaporation ponds in Eilat, Israel. Aquat Microb Ecol56:275-284

Suggett DS, Stambler N, Prášil O, Kolber Z and others (2009) Nitrogen and phosphorus limitation of oceanic microbial growth during spring in the Gulf of Aqaba. Aquat Microb Ecol 56:227-239

Ter Braak CJF, Šmilauer P (1998) CANOCO reference manual. Microcomputer Power, Ithaca, New York

van de Meene AML, Le Olson T, Collins AM, Blankenship RE (2007) Initial characterization of the photosynthetic apparatus of 'Candidatus Chlorothrix halophila', a filamentous, anoxygenic photoautotroph. J Bacteriol 189:4196-4203

Veselá J (2006) Benthic algal communities and their ecology in sandstone periodically desiccated brook in National Park Bohemian Switzerland (Czech Republic). Czech Phycology 6:99-110

> Woelfel J, Sørensen K, Warkentin M, Forster S, Oren A, Schumann R (2009) Oxygen evolution in a hypersaline crust: in situ photosynthesis quantification by microelectrode profiling and use of planar optode spots in incubation chambers. Aquat Microb Ecol 56:263-273

Yurkov VV, Csotonyi JT (2003) Aerobic anoxygenic phototrophs and heavy metalloid reducers from extreme environments. In: Pandalai SG (ed) Recent research developments in bacteriology, Vol 1. Transworld Research Network, Trivandrum, p 247-300

Yurkov VV, Csotonyi JT (2009) New light on aerobic anoxygenic phototrophs. In: Hunter CN, Daldal F, Thurnauer MC, Beatty JTh (eds) The purple phototrophic bacteria. Springer, Dordrecht, p 31-55

Submitted: December 4, 2008; Accepted: April 16, 2009 Proofs received from author(s): June 5, 2009 